\title{
Exploring the most influential papers in Vietnam's entrepreneurship in the past ten years
}

Ho Manh Toan

AISDL

Hanoi, Vietnam

January 14,2021

This short explorative article looks at the list of papers on Vietnam's entrepreneurship in the past ten years.

The study used Google Scholar and the number of citations to determine the influential papers. "Vietnam's entrepreneurship," "Vietnam entrepreneurship," "Vietnamese entrepreneurship" are searched keywords. The results are presented in Table 1.

Table 1. Most cited papers from the Google Scholar database

\begin{tabular}{|l|l|l|l|}
\hline \multicolumn{1}{|c|}{ Paper } & $\begin{array}{c}\text { Yea } \\
\mathbf{r}\end{array}$ & $\begin{array}{l}\text { Citation } \\
\text { s (as of } \\
\mathbf{1 4 - 0 1 -} \\
\mathbf{2 0 2 1}\end{array}$ & $\begin{array}{c}\text { Not } \\
\mathbf{e}\end{array}$ \\
\hline $\begin{array}{l}\text { The factors affecting entrepreneurial intention of the students } \\
\text { of Vietnam national university-a mediation analysis of } \\
\text { perception toward entrepreneurship }\end{array}$ & 2016 & 154 & {$[1]$} \\
\hline $\begin{array}{l}\text { Transnational entrepreneurship amongst Vietnamese businesse } \\
\text { s in London }\end{array}$ & 2015 & 70 & {$[2]$} \\
\hline $\begin{array}{l}\text { Female entrepreneurship in rural Vietnam: an exploratory } \\
\text { study }\end{array}$ & 2014 & 61 & {$[3]$} \\
\hline $\begin{array}{l}\text { Social capital and female entrepreneurship in rural regions: } \\
\text { Evidence from Vietnam }\end{array}$ & 2012 & 59 & {$[4]$} \\
\hline $\begin{array}{l}\text { Capital constraints and the performance of entrepreneurial } \\
\text { firms in Vietnam }\end{array}$ & 2014 & 58 & {$[5]$} \\
\hline $\begin{array}{l}\text { The entrepreneurial facets as precursor to Vietnam's economic } \\
\text { renovation in 1986 }\end{array}$ & 2011 & 55 & {$[6]$} \\
\hline
\end{tabular}




\begin{tabular}{|l|l|l|l|}
\hline $\begin{array}{l}\text { Impacts of geographical locations and sociocultural traits on } \\
\text { the Vietnamese entrepreneurship }\end{array}$ & 2015 & 52 & {$[7]$} \\
\hline $\begin{array}{l}\text { Woman entrepreneurship in rural Vietnam: Success and } \\
\text { motivational factors }\end{array}$ & 2015 & 48 & {$[8]$} \\
\hline $\begin{array}{l}\text { Vietnam in transition: SMEs and the necessitating environment } \\
\text { for entrepreneurship development }\end{array}$ & 2015 & 43 & {$[9]$} \\
\hline $\begin{array}{l}\text { The relationship between perceived access to finance and } \\
\text { social entrepreneurship intentions among university students } \\
\text { in Vietnam }\end{array}$ & 2018 & 32 & {$[10]$} \\
\hline $\begin{array}{l}\text { Household entrepreneurship and social networks: Panel data } \\
\text { evidence from Vietnam }\end{array}$ & 2018 & 31 & {$[11]$} \\
\hline $\begin{array}{l}\text { Computational entrepreneurship: From economic complexities } \\
\text { to interdisciplinary research }\end{array}$ & 2019 & 31 & {$[12]$} \\
\hline $\begin{array}{l}\text { It takes two to tango: Entrepreneurship and creativity in } \\
\text { troubled times-Vietnam 2012 }\end{array}$ & 2012 & 25 & {$[13]$} \\
\hline Female entrepreneurship: evidence from Vietnam & 2015 & 24 & {$[14]$} \\
\hline $\begin{array}{l}\text { Factors affecting entrepreneurial intentions among youths } \\
\text { in Vietnam }\end{array}$ & 2019 & 24 & {$[15]$} \\
\hline $\begin{array}{l}\text { Explaining micro entrepreneurship in rural Vietnam-a } \\
\text { multilevel analysis }\end{array}$ & 2018 & 20 & {$[16]$} \\
\hline $\begin{array}{l}\text { Entrepreneurship and creativity in transition turmoil: the case } \\
\text { of Vietnam }\end{array}$ & 2013 & 14 & {$[17]$} \\
\hline
\end{tabular}

Previous studies suggested there are not many papers on Vietnam's entrepreneurship [18, 19]. However, the fields have started to attract more attention because of the stable development of Vietnam [20]. From a small number of only 349,000 small-and-medium enterprises (SMEs), approximately 600,000 SMEs have been active in 2018 [22]. The SMEs contributed up to $40 \%$ of Vietnam's GDP, which is expected to surpass US $\$ 1000$ billion, PPP-adjusted, soon.

Thus, despite certain shortcomings, such as the lack of focus on cultural aspects, entrepreneurship research has expanded its influence on essential topics: gender, student' entrepreneurial intentions, or creativity. In Table 1, there are four articles discussing the role of entrepreneurship to women $[3,4,8,14]$. Meanwhile, a paper on factors affecting the entrepreneurial intention of Vietnamese students is the most cited paper in the field [1]. In the future, the role of entrepreneurship in fostering environmentally friendly awareness and biodiversity conservation [23].

Notably, $64 \%$ of the papers in Table 1 were published in the latter half of the last decade. Evidently, a paper that was published in 2019 [12] has gained significant momentum. The high percentage of papers from 2015 onward suggested entrepreneurship research is just getting warmed up. Amidst the 
uncertainty of a post-COVID-19 era, the role of entrepreneurship will be more important to the society.

\section{References}

[1] Khuong, M. N., \& An, N. H. (2016). The factors affecting entrepreneurial intention of the students of Vietnam national university-a mediation analysis of perception toward entrepreneurship. Journal of Economics, Business and Management, 4(2), 104-111.

[2] Bagwell, S. (2015). Transnational entrepreneurship amongst Vietnamese businesses in London. Journal of Ethnic and Migration Studies, 41(2), 329349.

[3] Nguyen, C., Frederick, H., \& Nguyen, H. (2014). Female entrepreneurship in rural Vietnam: an exploratory study. In Kate L., Colette H., Elizabeth J. G., and John W. (Eds.). Women's Entrepreneurship in the 21st Century. Edward Elgar Publishing.

[4] Poon, J. P., Thai, D. T., \& Naybor, D. (2012). Social capital and female entrepreneurship in rural regions: Evidence from Vietnam. Applied Geography, 35(1-2), 308-315.

[5] Tran, H. T., \& Santarelli, E. (2014). Capital constraints and the performance of entrepreneurial firms in Vietnam. Industrial and Corporate Change, 23(3), 827-864.

[6] Vuong, Q. H., Nhue, D. V., Van Houtte, D., \& Tran, T. D. (2011). The entrepreneurial facets as precursor to Vietnam's economic renovation in 1986. The IUP Journal of Entrepreneurship Development, 8(4), 6-47.

[7] Vuong, Q. H. (2016). Impacts of geographical locations and sociocultural traits on the Vietnamese entrepreneurship. SpringerP/us, 5(1), 1189.

[8] Le, Q. V., \& Raven, P. V. (2015). Woman entrepreneurship in rural Vietnam: Success and motivational factors. The Journal of Developing Areas, 57-76.

[9] Nguyen, Q. A., Sullivan Mort, G., \& D'Souza, C. (2015). Vietnam in transition: SMEs and the necessitating environment for entrepreneurship development. Entrepreneurship \& Regional Development, 273-4), 154-180.

[10] Luc, P. T. (2018). The relationship between perceived access to finance and social entrepreneurship intentions among university students in Vietnam. The Journal of Asian Finance, Economics, and Business, 5(1), 6372. 
[11] Nguyen, C. H., \& Nordman, C. J. (2018). Household entrepreneurship and social networks: Panel data evidence from Vietnam. The Journal of Development Studies, 54(4), 594-618.

[12] Vuong, Q. H. (2019). Computational entrepreneurship: From economic complexities to interdisciplinary research. Problems and Perspectives in Management, 17(1), 117-129.

[13] Napier, N. K., Vu, D., \& Vuong, Q. H. (2012). It takes two to tango: Entrepreneurship and creativity in troubled times-Vietnam 2012. Sociology Study, 2(9), 662-674.

[14] Zhu, L., Kara, O., Chu, H. M., \& Chu, A. (2015). Female entrepreneurship: evidence from Vietnam. Journal of Business and Entrepreneurship, 26(3), 103.

[15] Nguyen, A. T., Do, T. H. H., Vu, T. B. T., Dang, K. A., \& Nguyen, H. L. (2019). Factors affecting entrepreneurial intentions among youths in Vietnam. Children and Youth Services Review, 99, 186-193.

[16] Sohns, F., \& Diez, J. R. (2018). Explaining micro entrepreneurship in rural Vietnam-a multilevel analysis. Small Business Economics, 50(1), 219-237.

[17] Vu, D. L. N., Napier, N. K., \& Hoang, V. Q. (2013). Entrepreneurship and creativity in transition turmoil: The case of Vietnam. In V. Ribiere \& L. Worasinchai (Eds.), Proceedings of the International Conference on Management, Leadership and Governance (pp. 329-340). Bangkok University ICMLG 2013. United Kingdom: Academic Publishing.

[18] Vuong, Q. H., et al. (2020). What have Vietnamese scholars learned from researching entrepreneurship?: A systematic review. Heliyon, 6, e03808.

[19] Vuong, Q. H., et al. (2020). Multi-faceted insights of entrepreneurship facing a fast-growing economy: A literature review. Open Economics, 3(1), 25-41.

[20] Chính, P. M., \& Hoàng, V. Q. (2009). Kinh tế Việt Nam: Thăng trầm và đột phá. Nxb Chính trị Quốc gia, Hà Nội.

[21] Vuong, Q. H., \& Tran, T. D. (2009) The cultural dimensions of the Vietnamese private entrepreneurship. IUP Journal of Entrepreneurship Development, $V I(3-4), 54-78$.

[22] Ministry of Planning and Investment. (2020). 2020 Vietnamese Enterprises White Book. Nxb Thống kê. 
[23] Vuong, Q. H. (2021). The semiconducting principle of monetary and environmental values exchange. Economics and Business Letters, 10(3), article in press. 